\title{
Analysis of Elderly Women's Needs in Slum Area of Medan City
}

\author{
Asfriyati $^{1}$, Lita Sri Andayani ${ }^{2}$ \\ ${ }^{1}$ Faculty of Public Health Universitas Sumatera Utara, Indonesia \\ asfriyati@gmail.com \\ ${ }^{2}$ Faculty of Public Health Universitas Sumatera Utara, Indonesia \\ lita andayani@yahoo.com
}

\begin{abstract}
Life expectancy of women is higher compared to men, this affects the number of elderly women more than men. However, if the number of elderly women are not qualified, it will be burden for development. In order to maximize the role of service to elderly, it is needed to know first the needs of elderly women, in this case, the focus is in the slum region. The method used in this research is a quantitative approach. The population is elderly women in slum area. The study design uses quantitative approach. This research is located in the village of Bagan Deli district of Medan Belawan. Data collections are primary data and secondary data. To analyze problems, the model proposed is Structural Equation Model. Characteristics of elderly women aged 60-74 years at $79.6 \%$, with the most complete primary school education amounted to $93.8 \%$. Based on the Malay, the rate of elderly woman is $61.9 \%$, and the rate of widow is $61.9 \%$. Based on living alone, the rate is $\mathbf{4 6 . 0 \%}$ and the average rate of unemployed elderly women is $68,1 \%$. Majority of elderly women's income are helped by the families (children grandchildren) is $69.9 \%$ and according to the health status, majority of elderly women suffer from complaints such as arthritis, headaches, diabetes, heart disease, high blood pressure, gout and others are $75.2 \%$. The needs of the elderly woman in the slum area to update the information on the social activities is the most significant, basic needs for elderly women in slum area is the pension which is the most significant indicators of basic needs. The health needs that sense of comfort / tranquility which is the most significant indicator of health needs. The needs of the elderly women's work skills which are the most significant indicator of job requirements and the needs of elderly women for infrastructure and recreation facilities which are an indicator of facilities and infrastructure needs are the most significant. It is hoped that relevant parties can plan to meet the needs of elderly women in slum area to provide services according to the expected demand.
\end{abstract}

Keywords - Elderly Women's Need, Slum Area

\section{INTRODUCTION}

Indonesia is among the countries which entered the era of elderly (seniors) structured population because the population who are aged 60 years and over is approximately $7.18 \%$. In 2010 , the elderly amounted to 23.9 million $(9.77 \%)$, life expectancy 67.4 years and in 2020 was estimated at 28.8 million (11.34\%), with a life expectancy of 71.1 years. Of these number, in 2010, the number of elderly people living in urban areas is amounted to $12,380,321(9.58 \%)$ and those living in rural is amounted to $15,612,232(9.97 \%)$

Elderly residents of the last two years has a significant increase in 2007 , the number of elderly people amounted to 18.96 million increased to $20,547,541$ in 2009 [1]. This number is the fourth largest after China, India and Japan. Because the life expectancy of women is longer than men, the number of elderly women is more than the elderly men (11.29 million versus 9.26 million). Because of that, the problem of elderly in Indonesia, generally, is more dominated by women. The data of elderly people based on sex can be seen in Table 1 .

TABLE I

THE NUMBER OF ELDERLY PEOPLE BASED ON SEX IN SOUTHEAST ASIAN COUNTRIES AND INDONESIA IN 1970-2015

\begin{tabular}{|c|c|c|c|c|c|c|c|c|}
\hline \multirow{2}{*}{ Country/ Region } & \multicolumn{2}{|c|}{1970} & \multicolumn{2}{c|}{1995} & \multicolumn{2}{c|}{2025} & \multicolumn{2}{c|}{ 2050 } \\
\cline { 2 - 8 } & Women & Men & Women & Men & Women & Men & Women & Men \\
\hline $\begin{array}{c}\text { Southeast Asian } \\
\text { Region }\end{array}$ & 5,7 & 4,9 & 7,2 & 6,0 & 13,3 & 10,9 & 21,7 & 18,3 \\
\hline Indonesia & 5,5 & 4,9 & 7,2 & 6,3 & 13,8 & 11,6 & 23,1 & 20,0 \\
\hline
\end{tabular}


The number of senior citizens (above 60 years) in Medan city in 2010 about 117,216 inhabitants consist of 52,033 elderly men and 65,183 elderly women. From the data, it appears that the number of elderly women is more than the elderly men. Based on Mutiara research in Medan, it also acquires the characteristics of the elderly in the city are mostly women amounted to $68.9 \%$, while elderly men is $31.1 \%$.

Elderly residents in the city of Medan based on Central Bureau of Statistics indicate an increase. In 2000 , the number of elderly is $4.95 \%$ and in 2010 is increased to $5.58 \%$ and it is estimated to be $6.11 \%$ in 2020. Elderly residents who are not potential (sick, have no family) to received assistance from the budget of the State Budget (APBN) in Medan from 2007-2011 annually were only 60 elderly people who were given assistance, and in 2012 were issued to 171 elderly people who potentially are in the district and sub-district Marelan Belawan. Despite the increasing number, the number of elderly who were given assistance are still so far from the number of elderly who are not potential in Medan [2]

Health programs that include the community is local clinic, but from the obtained data apparently from all districts in the city of Medan. The number of senior citizens who served in 2010 is just as much as $54.01 \%$, which the active local clinic is only $31 \%$. From the results of Medan health care information, it is said that the elderly has not been served entirely because they lack infrastructure facilities and health workers specifically addressing the elderly [3]

The highest data of slum area in Medan ciy is in 8 districts in 11 villages and 30 region in the following order: 1). Medan Belawan, 2). Medan Marelan, 3). Medan Maimun, 4). East Medan, 5). Medan Amplas, 6). Medan Petisah 7). Medan Tembung 8). Medan Sunggal.[4]

From the eight sub-district which includes the highest slum, Medan Belawan is a district that most regions are included in the slums are Belawan $P$. Sicanang district, Bahari district, Bahagia district, and Belawan I district, Bagan Deli district [4]. For this study, Bagan Deli distric were selected considering the large number of elderly women in the village. The number of elderly in the slum area certainly has characteristics that make it more difficult conditions for the elderly. Therefore, it is necessary to study the elderly, especially elderly women residing in slums to obtain a policy needs and what can be done for the elderly women.

\section{LITERATURE REVIEW}

\section{A. Definition of Elderly}

World Organization and the World Health Organization (WHO) has not had a standard number of criteria, but the agreement point is 60 or older as old age limit. In Indonesia, a 60 years elderly and older are contained in Undang Undang No. 13 in 1998 on the Welfare of Elderly [5]. Classification of the elderly according as cited Maryam (2008) into five groups [6]:

1) Pre Elderly, a person aged between $45-59$ years.

2) Elderly, a person aged 60 years and older.

3) Elderly with high risk, i.e. a person aged 70 years or older.

4) Potential elderly, namely the elderly who are still capable of doing the job or activity that can make money.

5) Un-potential elderly, the elderly who are helpless and do the work or activities that depend on the help of others.

Under the rules of State Minister of women and children protection of the Republic of Indonesia No. 24 of 2010, elderly age group can be divided into [7]:

1) Age 60-69 years called young elderly.

2) Age 70-79 years called mid-elderly.

3) Age above 80 years called old elderly.

Elderly are also grouped by residence. Particularly the elderly woman can be grouped into (a) of elderly women who live alone (b) of elderly women who lived with the couple (c) of elderly women who lived with another family (kids / grandchildren).

\section{B. Needs of Elderly}

The need is something that is very desirable or needed someone of basic human needs is an element needed by humans in maintaining physiological and psychological balance. In addition to the basic necessities needed anyway as socialization, education, health, recreation and relationships between people. Not all need to have the same importance.

Needs can be classified as follows: 
a. Needs according to its intensity, which needs the light of the urgency.

b. Needs according to its nature, namely, the need by the impact or effect on the physical and spiritual.

c. Needs according to the time (present or future).

d. Needs according to form, ie including material needs.

e. Needs by subject, according to the needs of the parties - those in need (individuals or communities), as an example of the different individual needs of the elderly is the needs of adolescents, people's needs or the socalled collective needs such as public roads, lighting etc.

Needs of the elderly as well as people in general have the same basic needs, but due to the limitations of the physiological, psychological, and economic causes basic needs be met. According to the Ministry of Social Affairs is to fulfill the unique needs of the elderly physical needs, spiritual needs and social needs. To fulfill the needs, the development of a wide range services such as housing, care, recreation, financial, transportation, and the development of neighborhood environment.

The needs of elderly vary greatly in each stage of a different age. Between the age of 75-85 years often have serious disabilities and severe physical immobility and thus require specific anyway.

For elderly people who withdraw from social life then the aoutreach program is needed and the nature of services that must be delivered to the brand [8]. Psychological factors can also lead to different needs of elderly usually do not like the movement or the environmental transition would be done if they need counseling services.

\section{Definition of Slum}

Slums are neighborhoods that have deteriorated physically, economically, and culturally, and its location in accordance with the spatial plan of regency / city.

Law No.4 / 1994 on Housing and Human Settlements (article 5, 7, 27 and 28) Permenpera No. $22 / 2008$ on Minimum Service Standards for Housing. A slum neighborhoods that have deteriorated physically, economically, and culturally, and its location in accordance with the spatial planning district / city.

A sign of the strength of the symptoms of poverty, which is partly due to the presence of excessive urbanization, in the cities. In general, slums (slum area) is defined as an area of settlement or not a residential area used as living quarters conditioned buildings were substandard or unfit inhabited by the poor population is dense. region which were not designated as residential areas in many large cities, the poor people on low incomes and do not remain occupied to be a place to stay, such as riverbanks, on the edge of the railroad tracks, vacant lots around the factory or the city center, and under the bridge.

The traits of slum

1) Inhabited by a dense population and crowded, either because of population growth due to births even for their urbanization.

2) Inhabited by low-income and non-permanent, or produce subsistence living below the poverty line. The houses in this area is an emergency houses made of materials the former and not worth it.

3) Health and sanitation conditions are poor, usually characterized by the physical environment filth and easily spread infectious diseases. Scarcity of urban services such as water, toilet facilities, electricity, etc.

4) Unplanned growth that physical appearance was irregular and not neglected; narrow roads, the terrace does not exist, and so on.

5) Strong lifestyle "rural" are still traditional. socially isolated from other walks of life settlements. Illegally occupied land or legal status is unclear (problematic).

6) Usually characterized by a number of deviant behavior and crime. Related article: environmental history of the Kyoto protocol recognize global warming environmental carrying capacity of land degradation causes land degradation sense to know the greenhouse effect.

\section{RESEARCH METHOD}

The design study is using the quantitative approach. This research is located in the district of Medan Belawan because it is the highest of the data sub-district 8 slum area in the Medan. Bagan Deli district is a district located in the district of the slums of Medan Belawan. The population in this study were elderly women $\geq 60$ years old who live in the slums of Bagan Deli sub-district of Medan Belawan.

The primary data required in this study come from the population of elderly women in the slum district of Medan Belawan with structured interview method used interview guideline (questionnaire). Secondary data obtained from official publications in the form of annual reports 
from Medan City Health Office, Department of Social Welfare and Labor Medan, Women's Empowerment and Family Planning Medan, Medan Belawan sub-district journals, and books. To analyze problems with quantitative approach is using SEM.

\section{RESULT}

District of Bagan Deli is a research location. This district has an area of 230 hectares with a population of 15,860 inhabitants and has 15 neighbor hood, 4 of which are slum that is environmentally IV, VIII, X and XIV with an area of 7.43 ha site, the number of whole house as many as 379 units. The number of poor house holds amounted to 379 households and a population residing in slum areas have as many as 1,516 people. The charateristics of elderly include age, education, ethnicity, marital status, number of children, grandchildren, residence, employment status, income and health status. A description of the characteristics of the elderly can be seen in Table 2.

The results showed that the majority of elderly women who were in the slums of the city field 6074 -year-old majority of $79.6 \%$, based on the majority completed primary school education by $93.8 \%$. Based on the majority ethnic Malay ethnic elderly women of $61.9 \%$, the majority of elderly women have been widowed by $61.9 \%$. Based on residence majority of elderly women living alone alone amounted to $46.0 \%$ and the average elderly women do not work $68,1 \%$.

Based on the majority of the income of elderly women get help families (children / grandchildren) amounted to $69.9 \%$ and according to the st atus health complaints of the majority of elderly women mederita such as rheumatism, headaches, diabetes, heart disease, high blood pressure, gout and others $75.2 \%$.

TABLE II

DiSTRIBUTION CHARACTERISTICS OF ELDERLY WOMAN IN A SLUM AREA MEDAN 2015

\begin{tabular}{|l|l|l|}
\hline Characteristics & N & \% \\
\hline Age & & \\
\hline $60-74$ years old & 90 & 79,6 \\
\hline $75-90$ years old & 22 & 19,5 \\
\hline
\end{tabular}

\begin{tabular}{|l|l|l|}
\hline$>$ 90 years old & 1 & 0,9 \\
\hline Education & & \\
\hline Primary Graduate & 106 & 93,8 \\
\hline Junior High Graduate & 5 & 4,4 \\
\hline Senior High Graduate & 1 & 0,9 \\
\hline Diploma & 1 & 0,9 \\
\hline Tribe & & \\
\hline Jawa & 19 & 16,8 \\
\hline Batak & 19 & 16,8 \\
\hline Melayu & 70 & 61,9 \\
\hline Minang & 5 & 4,5 \\
\hline Martial Status & & \\
\hline Married & 43 & 38,1 \\
\hline Widow & 70 & 61,9 \\
\hline Resident & & \\
\hline Live alone & 52 & 46,0 \\
\hline Live with own couple & 32 & 28,3 \\
\hline Live with other family & 29 & 25,7 \\
\hline Job Status & & \\
\hline Employee & 36 & 31,9 \\
\hline Un-employee & 77 & 68,1 \\
\hline Income & & \\
\hline Pension & 3 & 2,7 \\
\hline Family's help & 109 & 96,4 \\
\hline Savings & 1 & 0,9 \\
\hline Health & 85 & \\
\hline Complain & 28 & 24,8 \\
\hline No Complain & $\mathbf{1 1 3}$ & $\mathbf{1 0 0 , 0}$ \\
\hline Total & & \\
\hline
\end{tabular}

\section{A. Information Requirements}

Based on the theoretical framework that is built, the variable information has five major indicators, namely improving health information (A1), increasing the income information (A2), employment information (A3), information skills (A4) and social activities (A5). After a confirmation test on the factor of five indicators of information needs. Construct reliability for variable information needs were found to be 0.919 and the AVE by 0698, which means better reliability. Therefore. Analysis of factors confirm the information needs to produce five indicators.

According to the order of magnitude of each load factor / SLF known that social activity 
information (A5), which is an indicator of the information needs is an indicator of the highest or most significant (SLF $=0.96$ ). The second subfactor in the variable information needs is the information skills (A4), followed indicator of improving health information (A1).

TABLE III

VARIABLE VALUE SLF ON INFORMATION NEEDS

\begin{tabular}{|c|c|c|c|c|c|}
\hline Latent Variable & $\begin{array}{c}\text { Manifest } \\
\text { Variable }\end{array}$ & SLF & Error & CR & AVE \\
\hline \multirow{3}{*}{$\begin{array}{c}\text { Needs of } \\
\text { information }\end{array}$} & A1 & 0,84 & 0,3 & & \\
\cline { 2 - 4 } & A2 & 0,68 & 0,54 & 0,91 & 0,69 \\
\cline { 2 - 4 } & A3 & 0,72 & 0,48 & 9 & 8 \\
\cline { 2 - 4 } & A4 & 0,94 & 0,11 & & \\
\hline & A5 & 0,96 & 0,08 & & \\
\hline
\end{tabular}

\section{B. Basic Needs}

Based on the theoretical framework is built, variable staples have three major indicators, namely old age security (B1), the food needs (B2) and housing (B3). After a confirmation test on the factor of three indicators of basic needs. Construct reliability for variable basic needs was found to be 0.946 and the AVE by 0859, which means better reliability. Therefore, analysis of factors confirm the basic requirement to produce three indicators.

According to the order of magnitude of each load factor / SLF known that old age security (B1), which is an indicator of basic needs is an indicator of the highest or most significant (SLF $=0.96$ ), food needs $(B 2)(S L F=0.92)$ and finally followed by housing which is lowest in sub factor basic needs $(\mathrm{B} 3)(\mathrm{SLF}=0.9)$.

TABLE IV

VARIable Value SLF on Basic NeEdS

\begin{tabular}{|c|c|c|c|c|c|}
\hline Latent Variable & Manifest Variable & SLF & Error & CR & AVE \\
\hline \multirow{3}{*}{ Basic Needs } & B1 & 0,96 & 0,08 & & \\
\cline { 2 - 4 } & B2 & 0,92 & 0,16 & \multirow{2}{*}{0,946} & \multirow{2}{*}{0,859} \\
\cline { 2 - 4 } & B3 & 0,9 & 0,2 & & \\
\hline
\end{tabular}

\section{Needs of Health}

Based on the theoretical framework that is built, the variable health needs have 5 great indicator that a routine examination $(\mathrm{C} 2)$, health insurance $(\mathrm{C} 3)$, sports activities $(\mathrm{C} 4)$, recreation (C5) and a sense of comfort / quietness (C6). After a confirmation test on the factor of five indicators of health needs. Construct reliability for variable information needs were found to be 0.965 and 0.850 for meaningful AVE good reliability. Therefore, analysis of factors confirm the health needs produce five indicators.

According to the order of magnitude of each load factor / SLF known that sense of comfort / quietness (C6) which is an indicator of health needs is an indicator of the highest or most significant $(\mathrm{SLF}=0.96)$. The second factor in the variable subhealth needs are sports activities (C4), followed by health insurance indicator (C3).

TABLE V

VARIABLE VALUE SLF ON HEALTH NEEDS

\begin{tabular}{||c|c|c|c|c|c|}
\hline Latent Variable & Manifest Variable & SLF & Error & CR & AVE \\
\hline \multirow{3}{*}{ Health Needs } & C2 & 0,9 & 0,19 & & \\
\cline { 2 - 4 } & C3 & 0,92 & 0,16 & \multirow{2}{*}{0,965} & \multirow{2}{*}{0,850} \\
\cline { 2 - 4 } & C4 & 0,93 & 0,13 & & \\
\cline { 2 - 4 } & C5 & 0,9 & 0,18 & & \\
\hline & C6 & 0,96 & 0,09 & & \\
\hline
\end{tabular}

\section{Job Needs}

Based on the theoretical framework that is built, the variable needs of the work has two major indicators, namely employment (D1) and the need for skills (D2). Once through to the second confirmatory test factor indicator needs some work. Construct reliability for the variable needs of the job was found to be 0.886 and the AVE by 0802 , which means better reliability. Therefore, analysis of factors confirm the need for jobs to produce 2 indicators.

According to the order of magnitude of each load factor / SLF known that skills (D2) which is an indicator of job requirements is an indicator of the highest or most significant $(\mathrm{SLF}=0.93)$ and the latter followed employment is lowest in sub factor needs some work.

TABLE VI

VALUE SLF ON VARIABLE JOB NEEDS

\begin{tabular}{|c|c|c|c|c|c|}
\hline Latent Variable & Manifest Variable & SLF & Error & CR & AVE \\
\hline Jobs Needs & D1 & 0,86 & 0,27 & 0,886 & 0,802 \\
\cline { 2 - 4 } & D2 & 0,93 & 0,14 & & \\
\hline
\end{tabular}

\section{E. Needs of Infrastructures}

Based on the theoretical framework that is built, the variable needs of infrastructure has four major indicators, namely the organization / group of elderly (E1), sports facilities (E2), recreational facilities (E3) and transport (E5). After a confirmation test on the factor of four indicators 
Construct facilities and infrastructure reliability to the variable needs of facilities and infrastructure was found to be 0.886 and 0.663 for meaningful AVE good reliability. Therefore, analysis of factors confirm the need for facilities and infrastructure resulted in four indicators.

According to the order of magnitude of each load factor / SLF known that the recreational facilities (E4), which is an indicator of its facilities and infrastructure is an indicator of the highest or most significant $(\mathrm{SLF}=0.88)$. The second factor in the variable sub facilities and infrastructure needs are sports facilities (E2), followed indicator of the organization / group of elderly (E1).

TABLE VII

VALUE SLF ON VARIABLE NEEDS INFRASTRUCTURES

\begin{tabular}{|c|c|c|c|c|c|}
\hline Latent Variable & $\begin{array}{c}\text { Manifest } \\
\text { Variable }\end{array}$ & SLF & Error & CR & AVE \\
\hline \multirow{3}{*}{$\begin{array}{c}\text { Needs of } \\
\text { infrastructure }\end{array}$} & E1 & 0,81 & 0,34 & & \\
\cline { 2 - 4 } & E2 & 0,84 & 0,3 & 0,88 & 0,66 \\
\cline { 2 - 4 } & E3 & 0,88 & 0,23 & 6 & 3 \\
\cline { 2 - 4 } & E4 & 0,72 & 0,48 & & \\
\hline
\end{tabular}

\section{CONCLUSIONS AND SUGGESTIONS}

\section{A. Conclusion}

Based on the results of the study, the research conclusion is:

1) Female characteristics in the slums of the majority of elderly women aged $60-74$ years at $79.6 \%$, with the most complete primary school education amounted to $93.8 \%$. Based on the majority ethnic, Malay ethnic elderly women of $61.9 \%$, a widow of $61.9 \%$. Based on residence majority of elderly women living alone alone amounted to $46.0 \%$ and the average elderly women do not work $68,1 \%$. Income majority of elderly women get help from families (children / grandchildren) amounted to $69.9 \%$ and according to the health status of elderly women suffering majority of the complaints such as arthritis, headaches, diabetes, heart disease, high blood pressure, gout and others $75.2 \%$.

2) The needs of the elderly woman in the slum area to update the information known that social activity is an indicator of the highest or most significant.

3) Basic needs for elderly women in slums known that old age security (B1), which is an indicator of basic needs of the highest or most significant.

4) The health needs known that sense of comfort / tranquility which is an indicator of the health needs of the highest or most significant.

5) Needs work of elderly woman is known that an indicator of the skills needs of the highest or most significant occupations

6) Infrastructure needs of elderly women known recreation facility which is an indicator of its facilities and infrastructure of the highest or most significant.

\section{B. Suggestions}

It is hoped that relevant parties can plan to meet the needs of elderly women in slums to provide services according to expected demand.

\section{REFERENCES}

[1] U.S. Census Bureau, International Data Base, 2009

[2] Dinas Sosial dan Tenaga Kerja Kota Medan, Aktivitas Kerja Penduduk Lansia, 2013

[3] Dinas Kesehatan Kota Medan, Profil Kesehatan Kota Medan Tahun 2010, 2011

[4] Dinas Perumahan dan Pemukiman Dat wilayah Kumuh Kota Medan, 2012

[5] Undang-Undang Republik Indonesia Nomor 13 Tahu 1998 tentang Kesejahteraan Lanjut Usia

[6] Maryam S, Mengenal Usia Lanjut dan Perawatannya , Salemba Medika, Jakarta, 2008

[7] Peraturan Menteri Negara Pemberdayaan Perempuan Dan Perlindungan Anak Republik Indonesia Nomor 24 Tahun 2010

[8] Mutiara Erna, Studi Identifikasi Karakteristik dan Kebutuhan Penduduk Lanjut Usia Di Kota Medan, Sumatera Utara, 2011.

[9] Notoatmodjo, Soekidjo, Kesehatan Masyarakat Ilmu dan Seni, Rineka Cipta, 